Boise State University

ScholarWorks

$12-1-2002$

\title{
Technical Communicators Beware: The Next Generation of High-Tech Recruiting Methods
}

Roger Munger

Boise State University 


\title{
Technical Communicators Beware: The Next Generation of High-Tech Recruiting Methods
}

-ROger MUnger

Manuscript received September 24, 2002; revised October 14, 2002.

The author is with the

Department of English,

Boise State University,

Boise, ID 83725-1525,

(email: rmunger@boisestate.edu).

IEEE DOI 10.1109/TPC.2002.805933

\begin{abstract}
This article presents an overview of how the internet has changed the way employers advertise vacancies and the way technical communicators search and apply for these openings. First, I explore the evolution of how employers have used the internet as a tool for identifying the best candidate for the job. Next, I review seven specific online recruiting strategies used by employers today. Finally, I describe major mistakes made by online job seekers and offer advice on how best to avoid or minimize these blunders. Included is a list of useful job search resources for technical communicators.
\end{abstract}

Index Terms-Employment, job boards, online recruiting, résumé-management systems, résumés, technical communication.

In the past, employers advertised open positions in "Help Wanted" sections of local newspapers. Technical communicators diligently scanned the Sunday classified ads for "Writers Wanted," typed their résumés and cover letters, dropped them in the nearest mailbox, and waited for a response. Both employers and job seekers had very few options. For employers, the newspaper industry had a virtual monopoly on the classified ads. Technical communicators read about the latest trend in résumé formats, designing professional portfolios, or approaches to "knock 'em dead" cover letters. However, for these job seekers the search process and application method did not change much until the internet became available.

The internet significantly changed the way employers recruit talent and this way technical communicators apply for jobs. Employers had a new way to advertise openings, and technical communicators had a new way to search for jobs. As employers developed new methods for their online recruiting efforts, old rules and strategies for job seekers no longer applied. For example, Peter Weddle cautioned, "The new job market is a whole new ball game, and it operates with a totally new set of rules. The techniques for conducting a job search campaign today are completely different from those that worked and worked well just five years ago" $[1, \mathrm{p}$. 3]. Change seems to be the only constant in searching for a job online. Therefore, successful job seekers must continually update their search strategies in response to employers' online recruiting methods.

Online recruiting has become a multibillion dollar business. Already established in large companies by the late 1990s, online recruiting and electronic résumé management methods are now frequently being used by smaller companies as well. Technical communicators who felt that they did not need to know anything about new job search methods 
because they were only interested in applying for "lone writer" positions at small companies can no longer feel safe in their approach. Joyce Kenney and Thomas Morrow warn, "Just because you are applying to a small company, don't assume your résumé will not be read by a computer" [2, p. 13]. Similarly, online job searches are not just for techies. An article in Fortune, for example, reports that "fully $65 \%$ of online job seekers hail from nontechnical professions" [3, p. 67]. While some technical communicators and employers are still managing to avoid the internet, this situation is not the norm. Technical communicators are searching for jobs and posting their credentials online at an astonishing pace. In response to the record numbers of job seekers going online, employers are developing new methods to attract, sort, screen, evaluate, and hire.

Unfortunately, the internet does not come with a sign announcing, "Job Seekers Beware." With online recruiting methods changing rapidly, job applicants have to learn the new rules as they go. However, in a high-stakes endeavor such as searching for a job, the trial-and-error approach makes many technical communicators uneasy. This article explores employers' new solutions to the old problem of finding the best candidate for the job, and describes several techniques used by online recruiters. It emphasizes steps technical communicators can take to use the internet to improve their chances of getting hired in a tight job market. Although much of this information and advice applies to job seekers from many professions, I draw on examples from my experiences in the technical communication field to illustrate my points.

\section{NeW Solutions to an OLd Problem}

The goal is still to efficiently hire and retain the best candidate for the position. However, the internet and new technology offer employers a variety of resources to help them in achieving their goal. Employers are both reacting to job seekers' online behaviors and attempting to change such behavior.

Early Online Efforts Job boards and résumé scanning were the first stage of online recruiting. Job boards were simply websites where employers posted available jobs and job seekers posted résumés. Employers liked job boards because they were cheaper, quicker, and more easily revised than print ads. Job seekers liked job boards because they could shop their résumés to hundreds of employers at once. At the same time, companies were developing electronic methods to manage and sort the huge volume of résumés they received.

As a result, early online efforts focused on résumé storage and retrieval. Recruiters needed an efficient way to store in an electronic format the hundreds of résumés they received each day. Once résumés were properly archived, recruiters needed an efficient way to find those applicants representing the best fit for a specific job opening. To solve the first problem, recruiters turned to scanning résumés. Traditional print résumés received through the U.S. mail or by fax were scanned into databases using optical character recognition technology. While many employers developed their own in-house hardware and software to scan résumés, a number of companies recognized the market need and began selling résumé-scanning services, résumé-scanning technology, and résumé-management (or tracking) software.

Résumé-scanning practices gave job applicants their first indication that traditional job-search practices would not work. Some job applicants were finding that employers could not accurately scan the résumés they had labored hours to create. For example, Baker, DeTienne, and Smart [4] report on the experiences of an MBA student who had his résumé returned because it was not in a format that allowed the company to scan his information. Photocopied and faxed résumés did not always scan properly. Similarly, dark color paper, unusual fonts, underlining, italics, bold, multiple-column layouts, horizontal and vertical rules, tight leading, narrow margins, and graphics all prevented employers from accurately scanning a résumé. Even simple mistakes such as a fold in the résumé running through the middle of a line of text often made the text scan as unrecognizable characters. In response to these problems, career counselors, websites, and books began offering job applicants advice on how to design a scanner-friendly résumé. Savvy technical communicators learned that if given the option of submitting a résumé online or sending a paper résumé, they should select the online option because many employers sent out the paper résumés to be scanned. The online résumé, therefore, got the applicant's credentials into the employer's database quicker.

Once résumés were transformed into electronic data and imported into company databases, employers turned to résumé-management technology. In a study examining how résumé-management systems were being used in Fortune 500 companies, Baker, DeTienne, and Smart found that " 54 percent have had their systems for over three years, 30 percent for one to three years, and 16 percent for less than one year" [4, p. 12]. For those companies without a résumé-management system, they reported that $52 \%$ planned to implement a system. They concluded from their study that résumé-management system use in Fortune 500 firms "appears to be sufficiently widespread that job applicants should assume their 
résumés will be entered into some type of [résumé-management] system" [4, p. 15]. While résumé-management technologies vary, they are all based on the same principle: résumés are converted to an electronic version through scanning or imported from electronic files and archived in a company's database.

To access résumés, employers search for keywords in much the same way that people search for information on the internet using search engines. For example, an employer interested in filling a software documentation position may use the following keywords: "software documentation," "technical writer," "RoboHELP," and "online help." KEYWORDS are typically nouns and noun phrases describing job experience, computer skills, trade organizations, and education level. Since keyword searches focus on nouns and noun phrases, applicants with résumés relying heavily on the old advice of "use active verbs" (for example, coordinated, supervised, trained, documented, etc.) are at a disadvantage since verbs are not typically used as search terms. Visit, for example, Rebecca Smith's eRésumés \& Resources (see Table I) for more information about creating keyword résumés.

Once employers entered the search parameters, résumés in the database featuring these keywords would be marked as a "match." More sophisticated software is capable of ranking résumés based on the number of "hits," sending letters (for example, acknowledgment, follow-up, reminders, offer, etc.)

TABLE I

Job-SEARCH REsources FOR TeChNiCAL COMMUniCATORS

\begin{tabular}{|c|c|c|}
\hline Sponsor/Source & URL & Description \\
\hline America's Job Bank (AJB) & ajb.org & $\begin{array}{l}\text { Developed by the U.S. Department of Labor, this site } \\
\text { is one of the Internet's largest sources of jobs online. }\end{array}$ \\
\hline $\begin{array}{l}\text { Wall Street Journal's } \\
\text { CareerJournal }\end{array}$ & careerjournal.com & $\begin{array}{l}\text { Free site offering advice, a searchable jobs database, } \\
\text { and news for job seekers and recruiters. }\end{array}$ \\
\hline Hoover's Online & hoovers.com & Good place to start researching companies. \\
\hline IMDiversity & imdiversity.com & $\begin{array}{l}\text { Site dedicated to connecting America's most } \\
\text { progressive employers with multicultural job seekers. }\end{array}$ \\
\hline $\begin{array}{l}\text { Richard Bolles' } \\
\text { JobHunterBible }\end{array}$ & jobhuntersbible.com & $\begin{array}{l}\text { Author of What Color is Your Parachute? provides a } \\
\text { collection of resources and an extensive library of } \\
\text { articles to help your job search. }\end{array}$ \\
\hline JobStar Salary Surveys & jobstar.org/tools/salary/index.htm & $\begin{array}{l}\text { Salary information, surveys, articles, and negotiation } \\
\text { strategies. }\end{array}$ \\
\hline $\begin{array}{l}\text { Joyce Lain Kennedy's } \\
\text { Careers }\end{array}$ & sunfeatures.com & $\begin{array}{l}\text { Selections from the nation's first syndicated careers } \\
\text { columnist. }\end{array}$ \\
\hline $\begin{array}{l}\text { National Writers Union } \\
\text { (NWU) Job Hotline }\end{array}$ & nwu.org & $\begin{array}{l}\text { Employers list contract jobs for free. Writers who find } \\
\text { a job through a listing pay a low finder's fee. }\end{array}$ \\
\hline $\begin{array}{l}\text { Rebecca Smith's eRésumés } \\
\text { \& Resources }\end{array}$ & erésumés.com & $\begin{array}{l}\text { Tutorials, examples, and advice for transforming an } \\
\text { existing résumé into electronic form. }\end{array}$ \\
\hline The Riley Guide & riley.guide.com & $\begin{array}{l}\text { Directory of career information sources and services } \\
\text { on the Internet. }\end{array}$ \\
\hline $\begin{array}{l}\text { Society for Technical } \\
\text { Communication (STC) }\end{array}$ & stc.org & Jobs database for use by STC members. \\
\hline TECHWR-L & raycomm.com/techwhirl/ & $\begin{array}{l}\text { An online service for technical communicators and } \\
\text { professionals and students in related fields featuring } \\
\text { career advice, employment services, and an active } \\
\text { discussion list. }\end{array}$ \\
\hline SunOasis Jobs & sunoasis.com & $\begin{array}{l}\text { Job database for writers, editors, and copywriters as } \\
\text { well as advice on finding writing jobs. }\end{array}$ \\
\hline $\begin{array}{l}\text { WITI: Women in Technology } \\
\text { International }\end{array}$ & witi.com & $\begin{array}{l}\text { Career opportunities source for women, including a } \\
\text { job database. }\end{array}$ \\
\hline $\begin{array}{l}\text { Write Jobs from Writers } \\
\text { Write }\end{array}$ & writerswrite.com & $\begin{array}{l}\text { Maintains a job database for use by both employers } \\
\text { and job seekers. }\end{array}$ \\
\hline
\end{tabular}


to applicants, and tracking travel expenses associated with hiring.

Résumé-management systems and keyword searches helped recruiters handle the influx of résumés. The problem, however, was that searching for candidates through the use of keyword searches only helped recruiters find résumés containing the keywords for which they were searching. A job board with 20 million unique résumés is virtually worthless if employers have no way of judging the fit between candidates and jobs. Employers quickly realized that keyword searches did not differentiate good applicants from mediocre ones. Moreover, unscrupulous technical communicators could skew the process by adding keywords to increase their chances of being found but that did not honestly describe their qualifications.

The lack of high-quality candidates and an inability to judge the best candidates from the thousands of poor fits gave rise to smaller, more-focused job boards called NICHE SITES. Niche sites may focus on such factors as type of job (for example, technical communication, engineering, computer science), location (for example, California, Japan, Australia), or employment needs (for example, full-time, part-time, consulting). For instance, the Society for Technical Communication's jobs database for technical communicators has been available online since 1996 . While these niche sites seem to be thriving today, they still require that both employer and job applicant find them on the internet.

About the same time niche sites were emerging, the dot-com boom of the late 1990s created a tremendous need for technology-savvy professionals. As a result, web-based auctions emerged. Sites such as ITAuctionHouse.com serve as online auction houses where full-time job seekers and consultants can have companies bid on their services. While these and other dot-com sites were heavy on flashy technology and excessive perks to recruit top candidates, they have lost popularity in the current economic climate and have been forced to replace the bells and whistles with more functionality for both employers and job seekers.

Even with job boards,

résumé-management systems, niche sites, and online auction houses, employers and job seekers were not satisfied. Many job seekers reported that posting a résumé online was the equivalent of sending it into a black hole [5], [6]. Both job seekers and employers could not keep up with the thousands of new job boards appearing each year. With some job boards averaging over 23,000 new résumés per day, recruiters just could not keep up. For example, Corsini states, "For many recruiters and consultants, online resources are, at best, supplementary to the core business of filling positions. They have neither the desire nor the resources to make expanded use of the Web" [7]. Moreover, for many companies, online recruiting generated only a small percentage of their hires. Job seekers and employers alike began to rethink their approaches to online job searches.

\section{Technical Communicator Behaviors Technical} communicators now enter the job market armed with several types of résumés. They have a hard copy résumé printed on high-quality stationary complete with design elements such as bulleted lists and bold type. They also have a scannable résumé printed on white paper without any embellishments. They have a no-frills electronic version saved as plain text and ready to be pasted into online applications or the body of an email message. More and more technical communicators are also turning to the internet as their first step in their search for a job.

Why are technical communicators increasingly going online to search for a job? Available 24-7, the internet can match any person's schedule and preferences. With a worldwide reach, applicants are not limited to their local area. Technical communicators can select from over 30,000 job boards and career sites. With such a reach, the internet greatly expands an applicant's network circle as well. For some technical communicators, meeting other people and networking online is a lot less intimidating than face-to-face encounters. Additionally, looking for a job online is like a treasure hunt; technical communicators never know what type of job opening they may find. It may be their dream job, or it may be a career path they have never considered.

Finding a job opening online enables technical communicators to demonstrate technology skills and a willingness to learn new skills. Actively using the internet to find a job demonstrates to prospective employers that the applicant has the technological savvy to succeed: "An e-mail address, a personal home page or a resume posted on-line are viewed as indicators that an applicant is willing to move into the future, use resources creatively and stay competitive in the marketplace" [8, p. 17]. In addition to demonstrating their technological savvy, job seekers representing a variety of professions are demonstrating to recruiters their preferences and expectations. For instance, in "Perception vs. Reality: Jobseeker Behavior Online," iLogos Research reports the results of a survey of more than 1,500 visitors to the Careers section of the corporate websites of four Fortune 500 companies. Findings about job seekers' online behavior include the following: 
- Only one out of eight corporate Career website visitors comes from job boards.

- Most corporate Career website visitors are employed; many are happily employed.

- Jobseekers appreciate details on how to apply online.

- Ninety-nine out of a hundred jobseekers expect an acknowledgment after applying online.

- For experienced candidates especially, anonymity is important.

- Candidates are ready to complement résumé information with additional profile information.

- Online candidates welcome questions about their skills.

- Candidates will spend the necessary time to apply online to a job of interest. [9]

Technical communicators also have the option of paying a résumé-distribution service to send their résumé to recruiters. Some of these services are a waste of money since they do little more than turn an applicant's résumé into spam and send it to every recruiter with an email address. Moreover, paying for such a service makes applicants, in the eyes of some recruiters, seem desperate and not very technologically confident. However, some newer résumé-distribution services are offering targeted distribution and privacy controls to clients. Recruiters and career counselors offer mixed opinions about whether résumé distribution services are worth the money.

Technical communicators are also using discussion lists and face-to-face networking opportunities to evaluate the effectiveness of their online job search strategies. For example, a question regarding the effectiveness of job boards provided participants on the TECHWR-L discussion list some feedback [10]. In response to the question, "How many times per week does your résumé get viewed on each job board, and how many contacts do you get per week on each job board?" answers varied from few hits and no contacts to several hits a week and multiple contacts. Many respondents saw a decrease in activity as the economic situation worsened in 2002. Respondents also saw an increase in activity after modifying their résumés (for example, changing keywords, updating skills, or simply opening and saving the file again).

Finally, career counselors report that some job seekers can become so focused on their job-search materials that it begins to adversely affect their health. For example, Karp describes a condition known as Compulsive Résumé Addiction (CRA) in which job applicants fixate on repeatedly revising their résumés and cover letters instead of re-evaluating their job-search process [11]. Job seekers with CRA think, "If I just had a better resume, I could have got that job." The significant changes to the job-search process brought about by the internet make such a focus on written materials a damaging behavior. Now more than ever, technical communicators need to understand the high-tech recruiting methods used by employers and adapt not only their written materials but also their job search techniques.

\section{Online Recruiting Today Online} recruiting is now an established practice in many companies, and more everyday are turning to the internet to solve their hiring troubles. In fact, a survey conducted by the online job search company Office Team found that the number of hiring managers who would rather receive résumés electronically than through the mail now stands at $48 \%$, a $44 \%$ point jump from just two years ago [12]. In its annual "Global 500 Website Recruiting 2002 Survey," iLogos Research found that 91\% of the Global 500 uses corporate websites for recruiting. Global 500 corporations using the corporate websites for recruiting in 2002 represent, for example, $100 \%$ of the companies in the healthcare sector, $98 \%$ of the companies in the manufacturing sector, and $95 \%$ of companies in the high-tech sector [13]. Such high percentages are noteworthy since these sectors employ a high number of technical communicators.

Recruiters today are using technology for more than just résumé storage and retrieval. Lefkow reports

In this current economic valley-typified by a rise in the number of candidates and a decrease in the number of jobs - the way that companies are using the Internet has changed dramatically. A fundamental mindset shift has resulted: the question has gone from, "How can I find qualified candidates?" to, "How can I identify the best candidate from an avalanche of qualified and unqualified candidates? [14]

Now companies are redesigning their sites to manage the accumulation of résumés. Consider, for example, that Charles Schwab \& Co receives about 15,000 résumés in a normal month [7]. Companies have turned to prescreening questionnaires and skill tests. Other companies ask applicants to complete lengthy online applications. Online recruiting now involves online recruitment advertising, human resource applications, and online assessment and training [15]. Online recruiters currently use the internet to advertise positions at job boards as well as directly marketing positions to qualified candidates. Even employee referral programs and affirmative action tracking are being moved online.

Finally, many companies are recognizing that online recruiting can save them money. Mizell reports, "Hiring via the Internet also costs between 50 and 90 percent less than more traditional 
methods, and the time spent filling a position has dropped from months or weeks to days or hours" [16]. She further explains, "Most sites charge between $\$ 50$ and $\$ 300$ for a 30-day listing, with corporate accounts usually available around $\$ 15,000$ annually for unlimited listings. On the other hand, an employment ad in the Sunday New York Times business section is more than $\$ 900$ per column inch" [16]. Some recruiters even feel that the cost savings from a web ad makes up for the extra time needed to sift through the responses. For instance, Bruun, remarks:

I would spend \$4,000-\$5,000

on print ads for a senior management search that might run a few days and yield only a handful of good résumés. Now I spend \$200 on a Web ad that runs for 30-60 days and I may get 175-200 responses, but still 30-40 will be good ones. With that kind of productivity, I don't mind having to do the screening [qtd. in [7]].

While troubles still exist, reductions in recruiting costs and impressive reach of the internet have made online recruiting a key tool for filling open technical communication positions as well. At present, online recruiting is shifting focus away from the traditional résumé to a variety of efficient techniques to sort and identify the best qualified candidate for a position. Rather than consulting only an applicant's résumé, companies are increasingly using the internet to create a detailed profile of applicants. The next section describes seven strategies online recruiters use to efficiently hire and retain the best candidate for the position.

\section{ONLINE-RECRUITING StRATEGIES REVEALED}

The new flexibility in recruitment has forced recruiters to learn new skills and new approaches to recruiting talent. In fact, with over 110 million job listings and
20 million "unique" résumés on the web at any given time, effective recruiters must now keep track of a dizzying array of online job sites and determine the best strategy for filling a specific opening [7]. In the following sections, I outline eight online-recruiting strategies used to recruit applicants in a number of professions, describing what technical communication applicants need to know.

\section{Employers Monitor Their Own Employees' J ob Search Activities While not a recruiting} strategy in itself, monitoring current employee's job search activities is a strategy used by human-resource personnel to retain talent and protect company secrets. It is also something about which technical communicators must be aware. With the arrival of the web, employees can now search for another job while sitting at their desks-and look productive to a casual passerby. Companies worry not only that they might lose talent but also that the employee might leave with sensitive company information. More and more companies, consequently, actively monitor their own employees' job-search activities. Human-resource personnel, sometimes dubbed "salvagers," surf the internet searching for employees "in the market" for another job. Once found, the company decides whether the employee is worth salvaging (that is, retaining). Stories abound at career sites about employees who lose their current job by posting a résumé online (see, for example, [17]).

To help job seekers avoid such uncomfortable encounters, some job boards allow applicants to "block" specified companies (for example, a technical communicator's current employer) from accessing their résumé. Of course, some salvagers merely register under a noncorporate email address. Other job boards encourage applicants to post an abbreviated résumé without any identifying data. Interested employers can send an email to the candidate requesting additional information. When talent is short and demand is high, employers are willing to do this. However, in a tight job market, employers are often unwilling to go this extra step. Why should they? They already have hundreds if not thousands of résumés sitting on their desk and in their databases.

\section{Employers Search for You in More Places Than J ust Mega-Résumé Sites Although} sites such as Monster have over 18 million résumés, some recruiters view the quality of candidates found on large job boards as low. Recruiters are interested in quality, not quantity. Savvy recruiters recognize the value of using the entire internet to recruit. Recruiters surf virtual communities (for example, Geocities), use search engines, and periodically distribute electronic recruiting newsletters. More aggressive recruiters use techniques with names such as flipping, datamining, X-raying, peeling, harvesting, and anchor searching. Online recruiters use these techniques to find key employees, résumés, biographies, email addresses, contact lists, directories, and URLs-all of which help recruiters find candidates for an open position. Companies also focus on candidates who are not even looking for jobs. Recruiters have found that some of the best hires are those people, known as passive candidates, who have the desired skills and are already happy in their current position.

As a job seeker, therefore, you should not limit your online job-search activities to posting your résumé to the top five mega-job sites. Consider establishing a presence in relevant virtual communities by contributing in a way that demonstrates your professional skills. For example, you can participate in appropriate chat rooms and discussion lists (for example, TECHWR-L). You 
can be an attractive passive candidate by being visible and active in professional organizations such as the Society for Technical Communication and the IEEE Professional Communication Society. You may also wish to consider uploading your résumé to a personal webpage. Since many recruiters use the word résumé as a search term, you may want to consider placing "Résumé of [Your Name]" at the top of your résumé if you make it available online.

\section{Employers Use Nonprofit Online-Employment Search}

Engines Large corporations such as Lockheed Martin, IBM, John Deere, Hewlett-Packard, and Sun Microsystems have joined to create online search engines for jobs posted on their corporate sites. In response to the high cost of advertising positions on the mega-boards, sites such as DirectEmployers.com were created to quickly direct applicants to corporate sites and managed by not-for-profit employer associations. DirectEmployers, for example, advertise that "job seekers can now search the Internet for employment opportunities, apply online directly to a company's website, and establish ongoing relationships with prospective employers-at a privacy level never before available on the Internet." Similarly, some big corporations such as Lucent Technologies and Sun Microsystems have built their own online recruiting sites. Accordingly, technical communicators should determine which companies are major employers in their region and go directly to corporate sites to look for openings. Likewise, you should consider using employment search engines managed by employer associations.

\section{Employers are Turning to Online Profiles Perhaps representing} the future of online job searches, more and more companies are abandoning the traditional résumé and directing applicants to fill out profiles rather than submit résumés. Alexander reports, "The profile results in a résumé-like data source that is much more detailed in specific skills and competencies and gives the recruiter a consistent format that matches tightly with the requirements of customer companies" [18]. Profiles are typically completed at a company's website. This helps standardize the information collected and speed its placement in a searchable database. Online profiles also shift the burden of mundane data entry from the recruiters to the applicants. Relatively new online profiles come in many formats. Applicants may enter data in text fields or use check boxes to indicate experience and skill level.

The one characteristic that all online profiles share is that they ask applicants for only the information the company wants. Recruiters no longer have to wade through a list of hobbies or high-school awards. Online profiles force applicants to get right to the point. Do you have experience with $X$ ? Are you certified? If so, when were you certified and what is your level of expertise? Profiles are also attractive to recruiters because they can administer personality assessments and skills tests at the same time. An applicant's work history, skills, accomplishments, personality assessment, and test scores combine to form his or her online profile in an employer's database. From an applicant's perspective, completing an online profile is usually a simple exercise in extracting information from the résumé and providing it to a company in the order and format the company wants. However, not everyone is happy with online profiles:

As we increase the use of online
profiles versus traditional
résumés, as we automate this
important process, we may
be eliminating a candidate's
ability to express his or her
uniqueness and personality.
Yet, these are still the important

intangibles companies need to identify in an applicant [qtd. in [7]].

Online profiles are relatively new and, consequently, both employers and technical communicators will need to monitor how profiles are being used in the technical communication profession and decide for themselves whether profiles are an effective substitute for résumés or if they are better used as supplements to résumés.

\section{Employers Post Only a Sample of Open Positions on J ob} Boards While one mega-job board advertises pricing as low as \$120 for a single job posting, posting multiple openings on job boards can get expensive. Imagine the cost of advertising positions online for a company such as Wal-Mart which has an annual turnover of 400,000 and worldwide hires 550,000 people each year-that is more than General Motors employs in total [qtd. in [19]]. Major corporations typically budget over a million dollars for advertising openings (not all technical communication, of course) on job boards. Concerned with this high cost of advertising on job boards, some companies have started to advertise only a select number of openings on job boards and devote more money to directing applicants to their corporate site. Harrington, for instance, reports that "some companies post only $25 \%$ of open jobs on the boards but put all jobs on their own corporate sites" [20]. Savvy technical communicators understand that not all openings will appear on job boards and go directly to company sites to look for more vacancies.

\section{Employers Use Headhunters and Spiders Headhunters, also known} as executive search consultants, are recruiting professionals who help employers find and hire the right person for the job. Typically, headhunters focus on a specific industry and look for candidates to fill middle- and senior-level 
positions. Headhunters fill an important need by helping employers identify individuals who can meet a company's very specific needs. They are also useful to technical communicators since these professionals represent yet another option for locating that perfect job.

Nevertheless, the internet has spawned a new species of unscrupulous headhunters. Anyone with an internet connection and website can call himself or herself a headhunter. Unscrupulous headhunters deal in quantity, not quality. They seek to dump as many résumés on a recruiter's desk as possible and hope one fits the company's needs. These headhunters not only grab résumés from inadequately protected job boards but also collect résumés posted on personal sites, and they think nothing of altering résumés to meet a client's needs. For example, job seekers have reported their résumés appearing on recruiters' desks listing advanced degrees they did not earn, language proficiency they do not have, and experience working at companies they have never seen before.

"Spidering" technology is another result of the boom in online job searches. In the rush to add résumés to their database and support claims of "we have X unique résumés," technology was developed that scours the internet collecting résumés from unprotected sites. Here is what one site says about its spider technology:

Our search engine continuously scans the web for résumés posted on personal web pages. We developed a web robot to continuously search the Internet twenty-four hours a day, seven days a week, three hundred and sixty-five days a year, looking for web documents containing résumés [21].
Once a spider has grabbed an applicant's résumé, it can be quickly distributed to hundreds of other sites or sold to dozens of employers. The result is that the applicant loses control of his or her résumé and has no idea where it is posted and who is looking at it. Some employers still find that casting such a wide net is effective. However, while spiders take the work out of collecting a truckload of résumés, many recruiters have found that during this economic downturn they have no trouble finding thousands of résumés at a click of a button. Moreover, they feel that most of the résumés caught in the spider's huge web lack quality.

\section{Employers Use Résumé- Screening and Management Software From a recruiters} perspective there is very little difference between 1,000 résumés in a database and 1,000 sitting in an inbox. The recruiter still has a labor-intensive task of wading through the résumés to fill the open position. In fact, the avalanche of poor-quality résumés generated by online services has made some recruiters question the value of online recruiting and yearn for the days of rifling through a small number of résumés kept in a metal file cabinet. King reports, "Some recruiters are ignoring online résumé services altogether because of the poor quality of résumés. Others say they cannot keep up with the growing number of Internet job sites" [22]. Other recruiters point to the increased workload:

We receive a steady flow of résumés from under qualified people, either from outside the United States or from those who simply don't fit the job description, but they send in résumés anyway in hopes of getting the attention of recruiters. This situation makes our job harder because we have to at least take a look at all the résumés that come through the system, and that takes time we don't have [qtd. in [7]].

What recruiters wanted was a more efficient way of locating candidates online. To meet this requirement, dozens of companies now provide tools to help recruiters manage the glut of résumés and efficiently fill openings. This résumé-screening and management software helps employers quickly sort through thousands of potential hires and select the best applicants.

Most résumé-screening software helps employers select applicants from a database containing thousands of résumés by still using keyword searches. Electronic recruiting software also helps employers screen résumés for careless errors and job hopping. Often the software can rank résumés based on the number and position of keywords, much like internet search engines do. More sophisticated systems can extract email addresses to send applicants an autoresponse email with pre-qualifying questions. These questions help eliminate the obviously unqualified applicants and identify those candidates truly interested in the position. I discuss questionnaires more fully in the next section. Specific tools help employers identify suspicious résumés and administer online assessments such as knowledge tests, workplace simulations, and personality profiles. Kotlyar and Ades report that such filtering can weed out $10-20 \%$ of the candidates [23].

The downside of résumé-screening software for technical communicators is that if your résumé does not contain the keywords an employer is searching for, your résumé will never be seen. In addition, recent lawsuits suggest that selecting applicants by certain keywords may discriminate against some applicants. Online recruiting is creating some legal headaches for companies, and it will take a while 
for human-resource departments to address these concerns.

As a job seeker, there is not much you can do about the type of résumé-screening software a company uses or the fact that a company recruits exclusively online. Your best strategy is to understand that employers screen résumés for keywords and make sure your résumé contains the keywords that both describe accurately your qualifications and are likely terms an employer would search for. Use well-recognized industry terms, typical technical communication genres (for example, online help, proposals, training manuals, etc.), professional associations, and the latest technical terms while avoiding terms unique to your company. How do you accomplish this? Read relevant technical communication trade publications (for example,

Technical Communication, IEEE TRANSACTIONS ON PROFESSIONAL COMMUNICATION, and Intercom), schedule informational interviews, network with colleagues, and ask mentors to review your materials.

\section{Employers are Testing Your Skills and Personality Employers} are still struggling with how to verify the accuracy of data available on job boards. Recruiters are finding that some online applicants will write almost anything to get an interview. To address this problem, employers are administering psychological, personality, and skills-based tests during all phases of the hiring process. Employers administer pre-qualifying and screening tests to initially narrow and refine the applicant pool. Later, qualified applicants take a variety of tests to help recruiters identify the best candidate for the position.

During the early stages of the process, companies have discovered that they can improve their selection process by combining résumé-screening technology with pre-employment online assessments. Recruiters use the web to administer simple prescreening tests (e.g., "Are you willing to relocate?") and more involved questionnaires. Testing done early in the process is often fully automated and designed to weed out unqualified candidates. Résumé scanning and evaluation technology is frequently used at this stage. Résumés are evaluated based on résumé content and job requirements. Recruiters also screen applicants' subject matter knowledge. Often such screening takes the form of an online machine-scored test. For example, a recruiter hiring for a technical writer position may test applicants' knowledge of a specific software program essential to job performance, basic technical communication concepts, or editing skills. The recruiter's early screening goal is to reduce the number of applicants he or she must evaluate.

Screening done later in the process focuses on specific characteristics useful in predicting a candidate's fit for a position. In light of recent corporate scandals, companies are realizing that personality and values matter just as much as hard skills when filling an open position. Later screening is more complicated because it attempts to gather information about an applicant's personality, values, cognitive skills, and judgment. Tests run the gamut from rating words, choosing adjectives that describe themselves, completing personality profiles, playing strategy games, completing problem-solving questionnaires, responding to work-based scenarios, and role playing. In fact, Mizzell reports that at one testing company "more than 2,500 types are available, from handwriting analysis to IQ tests" [16]. More sophisticated tests require applicants to respond to written or video simulations of job-specific situations. These tests ask an applicant to make a number of decisions during the simulation. Similar to the design-your-own-adventure books popular a few years ago, these simulations change in response to the actions applicants take at each decision point. Once data is collected, an employer can compare applicants' decisions to those made by other applicants and by experienced personnel currently employed by the company.

The result of these tests is a rich source of data on the skills applicants can bring to a job-specific task. If tests suggest, for instance, that the applicant is likely to steal company property, misuse sick days, harass women, or leave in a few months, even the best technical skills will not help such a candidate land the job. Ades and Kotlyar report that companies using recruiting technologies decrease employee turnover because they hire more qualified candidates [23]. In addition, skills scoring and matching technology reduces the human labor necessary to find the ideal applicant for an open position. Even job sites are beginning to screen and test job seekers wishing to post a résumé. Job boards are moving beyond the unrestricted no-questions-asked warehouse model of résumé services. King predicts, for instance, that with the current glut of unqualified candidates and avalanche of résumés, services such as confirming degrees, checking job histories, and performing background checks will become more common [22].

Although recruiters are finding out that such tests are more efficient than traditional interviews, they are also discovering that many applicants prefer these tests because they see them as less subjective [23]. As an applicant, it does not matter whether you prefer these tests or not. These tests are gaining in popularity, and job seekers should expect to take some type of employment test. Mizell explains, "Although an applicant has the right to 
refuse them, it's not illegal for an employer to ask for any test, even something as obscure and unproven as numerology" [16]. Although applicants cannot "prepare" for some of these tests such as personality tests, the best course of action is to answer them honestly. Second guessing a personality test is very difficult, and some of the more sophisticated ones have built-in mechanisms for catching applicants in a lie. For skills-based tests, technical communicators can prepare by reviewing core knowledge and skills essential to performing the job.

\section{ONLINE MISTAKES}

Just as the internet has made hiring more complicated for employers, so too has it made the job hunt more complicated for technical communicators. The internet's global reach, size, speed, and lack of privacy controls often lure technical communicators into making mistakes that will at best cause them to waste their time and money and at worst result in their getting fired or having their identities stolen. The following are the most common mistakes technical communicators can make while searching for a job online, including advice on how to avoid these mistakes.

\section{Searching for a J ob Using Your Current Employer's Resources Recruiters frequently} comment on how surprised they are at the numbers of applicants obviously using their current employer's email, phone, and time to search for another job. If applicants are searching for another job while on company time, recruiters assume they are not productively working. Moreover, if applicants feel free to waste their current employer's resources, recruiters worry what else they might feel free to do.

Advice: Search for a job on your own time. Avoid using company resources by getting a personal email account (many internet sites offer free email services). Do not be tempted to use your employer's printer, phone lines, mail supplies, or fax. Doing so may result in you losing your job (and possibly a good reference).

\section{Failing to Protect Your \\ Privacy Résumé theft is a} growing business for identity thieves. Take a look at your résumé and ask yourself what an identity thief may be interested in: your name, phone number, email address, postal address, detailed employment history, etc. Eager to find employment, job applicants provide identity thieves with an electronic treasure chest of data when they post materials to web-based databases. The threat of identity theft and a more general unease with posting confidential material on the internet are causing many applicants to rethink their online job-search strategies. For example, a recent article in Workforce reported, "Nearly 70 percent of executives' companies post jobs on the internet. However, 65 percent of the execs said that they wouldn't post their own résumés online, or that they had serious qualms about doing so" [24]. Both job boards and job seekers are guilty of practices that fail to protect confidential data.

Some job boards do not adequately disclose what they do with your résumés, contact information, and other personal data once you post it to the site. A site may share your data with other companies without your knowledge. Résumés you post directly to clients of a job site may end up posted to the job site as well without your knowledge or permission. For example, you may discover an opening for Company $\mathrm{X}$ while browsing the jobs database at MegaJobRUS.com. After following a link to Company X provided in the position announcement, you apply online for the job directly through Company X's site. However, without your permission, this information may be transmitted back to MegaJobsRUS. Unknown to you, you now have a résumé floating around the MegaJobsRUS database, when you thought you only had posted a résumé directly to Company X. Along comes a spider, and your résumé is now available at a hundred different job sites.

How companies handle sensitive data is changing, however. The Government's Employment Practices Data Protection Code, for instance, will make job boards offer applicants the option of sending an encrypted file. Still, some job boards are not embracing this legislation. Dillabough reports that job boards argue that this code will force them "to imply an unencrypted send is insecure when it is already highly unlikely that on online application would get into the wrong hands" [25]. While Employment Practices Data Protection Code and other efforts are steps in the right direction, you, as the applicant, still have the responsibility to investigate a site or service to make sure your private data remains private.

Applicants are also to blame. Some applicants provide too much information. They provide, for example, photos of themselves, dates of birth, and family information. Companies cannot legally ask for this information. However, applicants sometimes blindly supply it. Consider what a simple photo of a technical communicator and her family can reveal to employers: applicant's age, race, gender, marital status, sexual orientation, number of children, and children's ages.

Advice: Privacy should be a key factor when deciding at which job board to post your résumé. Read privacy policies of all newsgroups and job sites before posting your résumé. For an example of a good commitment to privacy, see JobOptions [26]. Consider using another site if it requires you to register and provide personal 
information. Check for job openings directly at company sites and avoid web-based databases by sending materials directly to the contact person at the company. Finally, do not help companies break the law by providing them with unsolicited and inappropriate personal information.

\section{Using Only One Search Engine or J ob Board Some job seekers} develop tunnel vision when searching for a job online. They tend to focus on only a single job board or use only one search engine (for example, google.com). Applicants, therefore, believe they have "seen all that is to be seen," when, in fact, hundreds of undiscovered openings exist. Each search engine follows different protocols for searching the internet and ranking sites for display. In fact, since some search engines allow customers to buy a high ranking, you cannot always be sure that the number-one listing represents the best fit for your search parameters. Moreover, every job board indexes openings using slightly different categories and search terms. With over 30,000 job sites on the internet, even posting your résumé at one the top five job sites may not be sufficient.

Advice: Try using several different search engines, including a few metasearch engines that search several stand-alone search engines at once. Once you find a few you like, learn how to use the engine's advanced search features. Also, check for job openings at several different job boards and try a variety of key words. For example, you may have better luck searching for "technical writer" at one site and "technical communicator" at another site. Evaluate your comfort level with posting your credentials online and then decide if placing your materials at more than one job board is right for you.

Failing to Critically Read the J ob Description Krumwiede laments, "Job ads have become a lot like horoscopes: every applicant thinks the job description describes them perfectly. Even if there isn't a fit at all, many job seekers subscribe to the philosophy, 'If I'm not right for this position, maybe there's something else within the company that I'm good for"' [27]. Some technical communicators have a mindset like the popular lottery commercial slogan "Hey, you never know." A desperate technical communicator with just a few clicks of the mouse can send his or her résumé to dozens of companies and job boards in just an afternoon. The result is that recruiters are overwhelmed with résumés, many from unqualified applicants. For instance, Krumwiede conducted a study to answer the questions, "How many unqualified applicants will submit their résumé to a job posting?" and "How much time do recruiters spend sifting through unqualified résumés?" He found that $70 \%$ of résumés submitted were unqualified, and résumé screeners devoted less than two minutes to each résumé [27]. Currently, technical communicators waste their time submitting résumés to positions for which they are not qualified, and employers waste their time reading them. The shotgun approach to landing a job is an inefficient use of your resources. Remember, you just might be asked for supporting materials, to take a test, or to schedule an interview. If you are not qualified, it will be obvious quickly. Unfortunately, you will have wasted valuable time that you could have spent getting hired for your dream job.

Advice: Know which skills and experiences are required and which are desired. Before you submit materials, ask, "Am I qualified for this position or am I playing the job seeker lottery?" While you may be eager for a job, avoid using ineffective strategies that label you as desperate. Such strategies make it more difficult to find $\mathrm{a}$ job and increase the chances of you finding a job that is a bad fit.
Ignoring Directions Was that a formatted or ASCII résumé? U.S. mail, fax, or email? The ability to follow directions seems to be a basic job skill-one in which technical communicators would want to demonstrate their proficiency. However, when it comes to applying for a job, especially online, some applicants seem to interpret the word directions as "here are some options, pick and choose, and do whatever fits your schedule." Recruiters need to receive your materials in a format that they can easily import into their databases. As recently as 1998, Baker, DeTienne, and Smart reported that almost $70 \%$ of companies they surveyed would manually input information from an unscannable résumé. Another 28\% would use written correspondence requesting resubmission [4]. Not today. The current glut of résumés has forced employers to ignore those applicants that cannot follow directions unless you are the best of the best in technical communication (and then why would you not follow basic directions?).

Recruiters take a dim view of technical communicators who fail to follow directions and cause them to waste time. For example, if directions ask you to paste your résumé directly into the body of an email message, including your résumé as an attachment will doom your chances of getting called for an interview. With software issues and the threat of viruses, recruiters are unlikely to open any attachment they do not specifically request. It does not matter how great your materials are if the recruiters cannot process them.

Advice: Follow submission guidelines. If the directions ask you to complete an online form, do not refer the recruiter to your website. Likewise, if the directions ask you to respond by U.S. mail, do not go looking for an email address. 


\section{Letting Fancy Design Overshadow Your Content With} traditional paper résumés, anything that departed from standard format slowed recruiters down. That included day-glow paper, colored type, spiraling print, graphics, multiple typefaces and sizes, and résumés designed to look like help manuals. Recruiters today want to be able to extract the information they need in the quickest time possible.

Nothing has changed now that technical communicators are preparing online job materials, except HTML and multimedia tools provide even greater temptations. Alexander states, "Recruiters say they don't like résumés created with ... HTML because the format takes too long to read. Also, the use of links requires that a recruiter go to the trouble of visiting a Web site to see information that should have been included in the résumé" [18]. HTML résumés also cause problems when they are imported into text-only database since the HTML code is lost. Similarly, animation, sound effects, and music are more likely to distract readers than help demonstrate your leading-edge technical skills. Finally, recruiters will rarely take the time to download special plug-ins and media players to view your online résumé.

Advice: Keep it simple. Make it easy for readers to navigate your résumé. Use descriptive headings typically used in the technical communication field. Use your résumé to demonstrate your understanding of business conventions and your ability to clearly communicate. Rely on a professional portfolio (print or online) to provide examples of your leading-edge skills (see [28], for a discussion on portfolios).

Making False Claims The ease of posting anonymous résumés on the internet has induced some technical communicators to inflate or misstate their credentials. While this has always been a problem with traditional print job-search materials, the problems seems to be compounded by the relative anonymity afforded by the internet. Recruiters have no way of ascertaining the authenticity of online materials. Applicants claim that they have "in-hand" certifications, degrees, and training they are currently completing or plan to complete in the future. Some technical communicators use keywords that do not accurately describe their skills but that they think prospective employers will use to search. They overstate salaries and employment experience. Burned by résumé fraud, more and more companies are prescreening applicants, checking backgrounds, contacting references, administering tests, and quizzing candidates during preliminary interviews to make sure a technical communicator's responses match what was submitted.

Advice: Tell the truth. It is OK, as Carliner recommends, to show some discretion by presenting your credentials "in a way that calls attention to your assets and deflect attention from your perceived liabilities" [29, p. 22]. Just do not be dishonest. You may get an interview through fraud but you will waste your time, damage your reputation, and ensure that you will never work for that company.

\section{Thinking Online Submissions are Informal Recruiters are} dismayed at the frequency of spelling and grammatical errors on materials received. While this may seem like another old problem, the problem is getting worse. With over 1.4 trillion email messages sent from North American businesses in 2001 [30], many email messages tend to be informal and sloppy. For example, emails often lack punctuation and proper capitalization, include spelling errors, use emoticons (for example, a smiley face), and rely on informal abbreviations (for example, TIA for Thanks in Advance). Some technical communicators treat electronic submissions of job materials in a similar manner. Careless errors, even in email messages or online forms, can hurt an applicant's chances of being hired.

Advice: Treat all correspondence (print and electronic) with a prospective employer as business correspondence. As such, materials should adhere to standard business conventions and etiquette. That means you need to carefully compose, edit, and proofread all materials before sending them. As a technical communicator, you will be held to an even higher standard. Resist the urge to send off a hasty reply to a follow-up message from a recruiter. Instead, you should take a moment to compose a message that presents your skills in the best possible light.

Forgetting the Cover Letter Like so much of the online job-search process, cover letters seem to be in transition. Do you need them or not? Do employers actually read them? Baker, DeTienne, and Smart report a study by Accoutemps that revealed that $60 \%$ of 150 executives surveyed believe a cover letter is as important as a résumé [4]. However, they also found in their own study that the majority of firms do no enter cover letters into their databases. The employers and recruiters I have talked to recently offer mixed views of the subject of cover letters. On the one hand, some admit they do not read them and, therefore, do not care if applicants include them. On the other hand, some find well-written cover letters very useful. Drake argues in an Intercom article that a cover letter provides applicants with an opportunity to accomplish three objectives:

- To state your reasons for writing and introduce yourself.

- To promote yourself and what you can do for the company. 
- To state what you would like to happen next. [31].

In short, cover letters allow you to "tell the reviewer ... in more than one way how you are going to use your technical communication, project management, and business development skills to contribute to the bottom line" [32, p. 10].

Advice: Include a cover letter, if possible. If the online submission option you are using such as an online form or profile does not provide space for a cover letter, you can omit it. However, if you are submitting your materials via email and the directions do not specifically tell you to not submit a cover letter, include a brief cover letter. Many employers still expect and read cover letters. Finally, take time to write an effective and error-free letter. A poorly crafted letter can seriously hurt your chances even though you may seem to have the required qualifications.

\section{Overlooking the Details}

Technical communicators seeking jobs online are trying to do too much, too quickly. In the rush to get their materials out to the most recruiters in the shortest time possible, some technical communicators fail to attend to the details that often make the difference in a tight job market. Besides not following submission guidelines, applicants email their materials to hundreds of recruiters in one email with all the recruiters' names displayed in the "To:" field. Another example of technical communicators' lack of attention to detail is using a generic file name such as "résumé.doc." Imagine the trouble recruiters have sorting through hundreds of such files. Some applicants send files infected with viruses.

Details make a difference. When submitting materials via an email message, technical communicators often fail to take advantage of the space seen first by many recruiters: the subject line in an email message. Unfortunately, some technical communicators leave the subject line blank and offer busy recruiters swamped with 1000 replies little incentive to open their message. More typically, technical communicators include generic phrases such as "Résumé" in the subject line. From a marketing perspective, this is a disaster.

Advice: Demonstrate your attention to detail and awareness of your reader's needs by attending to details such as the following:

- Keep your virus protection software current.

- Make sure only the recipient's name appears in the "To:" field.

- Use the subject line in your email message to provide a snapshot of your skills. An example for a software documentation position would be "Doc. Specialist/5 Yrs. Exp./MA TechComm/C++/US."

- Use informative labels (e.g., R_Munger_Résumé.doc) for your electronic materials.

- Send your materials only once. If you change your résumé, updates are acceptable if you do so infrequently and properly identify materials as updated.

- Get a separate email account for your job search. Make sure your email address is appropriate. WriteStud@mymail.com may not make the best first impression.

- Avoid typos when entering information directly into an employer's online form by first writing the material in a word-processing program. Use the spell check feature, save it as text only, and then paste the information into the form.

- Avoid awkward line breaks in material placed into email messages by limiting each line to no more than 65 characters.

- Help recruiters get your materials in the right job-specific folder by including any requested job codes (often placed in the subject line of an email submission).

\section{Thinking J ob Search Ends With} Your New J ob Of course, you should keep updating your résumé and maintaining your network circle even after you start a new job. You never know when your position might be eliminated. However, online job searches have created a number of additional tasks to be completed once a technical communicator secures a new job. One problem with posting your résumé online is that you lose control of it. Even though you may be off the market, your résumé may still be making the rounds thanks to unscrupulous headhunters and roving spiders. Your boss may get your résumé months after you have been hired. Now you have the awkward task of explaining that you are happy with your position and not looking for another job.

Advice: After the euphoria of getting hired wears off, take a few moments to check whether you have the option of removing outdated résumés. At the very least, date your résumé. Finally, do not end your search efforts when you receive a phone call offering you the job. Many things can happen (most of them bad) between the offer and your first day on the job.

\section{A Final Consideration}

An even bigger mistake, perhaps, than all of the ones I discussed above is the mistake of thinking that a successful job search consists solely of posting your résumé on several job boards. Posting a résumé online is just one of many activities a technical communicator must be doing while searching for a job. Richard Bolles, author of What Color is Your Parachute?, states that "for every 1,470 résumés sent floating around 'out there' by various job-hunters, only one job offer is made and accepted" [33]. He offers an even more sobering statistic regarding job boards:

Less than one half of one percent, if the job you are seeking is not computer-related; 20 percent if it is. That is: Out 
of every 100 computer people who post their résumés on the Internet, 20 of them will find a job as a result. I think 80 will not. And out of every 100 noncomputer people who post their résumés on the Internet, less than 1 of them will find $a$ job as a result. 99 will not [33].
Finding a job is a full-time endeavor. Once you post your résumé online, you still need to continue researching possible employers, following job leads found in print publications and online, networking face-to-face and online, and updating your skills. Table I lists several sources and tools for a successful job search. If finding a dream job were as easy as posting your résumé online and fending off the offers, everyone would be happily employed. While the internet has expanded technical communicators' job search strategies, getting hired still takes a lot of time and hard work.

\section{REFERENCES}

[1] P. D. Weddle, Electronic Résumés for the New Job Market: Résumés that Work for You 24 Hours a Day. Manassas Park, VA: Impact, 1995.

[2] J. L. Kenney and T. Morrow, Electronic Résumé Revolution, 2nd ed. New York: Wiley, 1995.

[3] J. Useem, "For sale online: You," Fortune, pp. 67-78, July 1999.

[4] W. H. Baker, K. DeTienne, and K. Smart, "How fortune 500 companies are using electronic management systems," Bus. Commun. Quart., vol. 61, no. 3, pp. 8-19, 1998.

[5] J. Dash, “Job board 'black hole'," Computerworld, vol. 33, no. 46, 1999.

[6] "Online résumés fall into blackhole," Computing Canada, vol. 27, no. 5 , p. 25, 2001.

[7] S. Corsini, "Wired to hire," Training, vol. 27, no. 5, pp. 50-54, 2001.

[8] C. Straub, Jobsearch.net. Menlo Park, CA: Crisp, 1998.

[9] Perception vs. Reality: Jobseeker Behavior Online. iLogos Research. [Online]. Available: https://www.ilogos.com/iLogosJobseekers/secure/medias/Jobseekers_Summary.pdf

[10] B. Byfield. (2002) How often is your résumé read on job boards?. [Online]. Available: http://www.raycomm.com/techwhirl/archives/0208/techwhirl-0208-01 172.html

[11] M. Karp, “Counseling compulsive résumé addiction,” Educational Res. Inform. Ctr. (ERIC), ED 456 374, 2001.

[12] G. Gallop-Goodman, "You've got résumés," Amer. Demographics, vol. 23, no. 1, p. 26, 2001.

[13] Global 500 Website Recruiting 2002 Survey. iLogos Research. [Online]. Available: https://www.ilogos.com/iLogosReport2002/secure/medias/Global500_2002Survey.pdf

[14] D. Lefkow. Is your online recruiting scalable?. Electronic Recruiting Exchange. [Online]. Available: http://www.erexchange.com/Articles/default.asp?CID $=\{B 2 D 65 E 8 B-$ 2571-4C67-8011-8025B4742A78\}

[15] K. Bedore. Online recruiting evolves. Electronic Recruiting Exchange. [Online]. Available: http://www.erexchange.com/Articles/default.asp?CID $=\{56 \mathrm{~A} 37134-\mathrm{EFF} 4-43 \mathrm{CA}-\mathrm{A} 276-18 \mathrm{EF} 4 \mathrm{AA} 16 \mathrm{E} 66\}$

[16] L. Mizell, "Résumés and Rorschach tests: Using high-tech recruiting methods to fill job vacancies," Office Solutions, vol. 18, no. 9, 2001.

[17] K. Jones, "Playing with fire," Kiplinger's Personal Finance Mag., vol. 54, no. 4, p. 36, 2000.

[18] S. Alexander, "Demise of the HTML résumé," Computerworld, vol. 34, no. 4, p. 46, 2000.

[19] Career Update Newslett., vol. 8, no. 1, p. 3, 2001.

[20] A. Harrington, "Can anyone build a better monster?," Fortune, vol. 145, no. 10, pp. 189-91, 2002.

[21] About WebsBestRésumés. WebsBestRésumés. [Online]. Available: http://websbestrésumés.com/more.html

[22] J. King, "IS: Point-and-click recruiting falls short," Computerworld, vol. 31 , no. 6, p. $1,1997$.

[23] I. Kotlyar and K. Ades, "Don't overlook recruiting tools," HRMagazine, vol. 47, no. 5, pp. 97-100, 2002.

[24] "Executives shy from posting résumés online," Workforce, vol. 79, no. 5, p. 25, 2000.

[25] C. Dillabough, "Job sites fear data protection ruling will scare off applicants,” New Media Age, p. 1, Apr. 2002. 
[26] Privacy Policy. JobOptions. [Online]. Available: http://ww1.joboptions.com/careertools/privacy.jsp?session_id=0\&app_id $=0$

[27] J. Krumwiede. Losing the résumé battle. Electronic Recruiting Exchange. [Online]. Available: http://www.erexchange.com/Articles /default.asp?CID $=\{$ DB439 610-9604-4F3D-A77B-4C95C51EFDOA $\}$

[28] J. Scott, "Portfolios for technical communicators: Worth the work," Intercom, pp. 26-28, Feb. 2000.

[29] S. Carliner, "Job hunting after thirty-five," Intercom, pp. 20-22, July/Aug. 2002.

[30] Managing e-mail overload. ePolicy Inst.. [Online]. Available: http://epolicyinstitute.com/press/wh1.html

[31] C. Drake, "Cover letters that sell you," Intercom, pp. 16-17, Apr. 2002.

[32] D. Le Vie, "Résumés: You can’t escape," Intercom, pp. 8-11, Apr. 2000.

[33] R. Bolles. The net guide: Your résumé. JobHuntersBible.com. [Online]. Available: http://www.jobhuntersbible.com/résumés/fgmrésumés.shtml

Roger Munger is an assistant professor of technical communication at Boise State University, where he teaches in the graduate and undergraduate programs. He is a frequent speaker on the topics of online job searches and professional portfolios for technical communicators. 